\title{
Technological properties of clay raw materials
}

\author{
O.M. Nedbailo (0000-0003-1416-9651), O.G. Chernyshyn (0000-0001-7702-894X)
}

The State Enterprise "Engineering Center "Drying"” Institute of Engineering Thermophysics of NAS of Ukraine, str. Bulakhovskogo, 2, Bldg. 2, Kyiv, 03164, Ukraine

Tel.: +380444240279, tel./fax +380444243283

E-mail: icsushka@gmail.com

Article info: received 02.11.2020, revised 24.11.2020, accepted 21.12.2020

Nedbailo, O.M., Chernyshyn, O.G. (2020) Technological properties of clay raw materials 4(49), DOI: $10.26909 /$ csl.4.2020.1

The article summarizes and analyzes the technological characteristics of various clay raw materials. Recommendations on the feasibility of their use in various types of ceramic production are given. Their main characteristics are given, such as chemical composition, mineralogical and physical properties, which vary within extremely wide limits. They are most characterized by a layered structure. All clay minerals are considered as secondary geological formations that arose in deposits in which water was present as a product of changes in aluminosilicate rocks. Most clay minerals are the product of weathering and deposition, but they can also be formed in hydrothermal conditions.

In addition to basic clay minerals, clays also contain various amounts of other minerals that often affect their behavior when used. The most common such minerals are quartz, feldspar and minerals containing iron, lime, alkalis and soluble salts. The organic component is also found in many clay deposits. Different classifications of clays are based on their geology, mineralogy, composition, properties and uses, but none of them covers all possible diversity.

Key words: clay raw materials, technological characteristics of ceramic production.

\section{Технологічні властивості глинистих сировинних матеріалів}

\author{
О.М. Недбайло, О.Г. Чернишин
}

Державне підприємство «Інженерний иеентр «Сушка»» Інституту технічної теплофізики НАН України, Київ, Україна

У статті узагальнені та проаналізовані технологічні характеристики різних глинистих сировинних матеріалів. Надані рекомендації щодо доцільності їх використання у різних видах керамічних виробництв. Наведені їхні основні характеристики, такі як хімічний склад, мінералогічні та фізичні властивості, що змінюються в надзвичайно широких межах. Для них найбільш характерна шарувата структура. Всі глинисті мінерали розглядаються як вторинні геологічні утворення, що виникли в родовищах, в яких була присутня вода як продукт зміни алюмосилікатних гірських порід. Більшість глинистих мінералів $є$ продуктом вивітрювання і осадження, але вони можуть також утворитися в гідротермальних умовах.

\section{Вступ}

У керамічних виробах глини виконують дві важливі функції. По-перше, вони надають масам пластичність, що необхідно для більшості зазвичай використовуваних процесів формування. Здатність водно-глинистих композицій формуватися і зберігати міцність і форму в процесі сушіння і випалу є основою більшості керамічних процесів. По-друге, глини спікаються (в температурному інтервалі, що залежить від їх складу) таким чином, що відбуваються при цьому ущільнення і зміцнення не викликають втрати форми виробів. Дуже чисті глини вогнетривкі, а забруднені плавляться при відносно низькій температурі.

Мета роботи полягає в систематизації науково-технічної інформації щодо фізико-хімічних та технологічних властивостей глинистої сировини для керамічних виробництв. 


\section{Матеріали та методи дослідження}

Зазвичай глинисті мінерали можуть бути класифіковані відповідно до їх структурної будови на каолінітову, монтморилонітову та іллітову (гідрослюдову) групи. Також встановлено [1], що мінерали хлоритової групи є найважливішою складовою частиною більшості родовищ глин. Запропонована класифікація грунтується на кристалічній структурі глинистих мінералів.

Властивості глин змінюються не тільки в залежності від мінералогічної групи. Вони залежать також і від умов утворення даного родовища. Каолін, зазвичай, класифікується як осадова речовина, тобто така, що залишилися після утворення на тому ж місці. Або іiі можна розглядати як вторинну (переміщену), тобто таку, що після утворення була переміщена під дією вітру або води і відкладена знову на деякій відстані від місця ії утворення. На рис. 1 показана фотографія мікроструктури каоліну при дослідженні його за допомогою електронного мікроскопа Opton IBAS із збільшенням в х17800 разів.

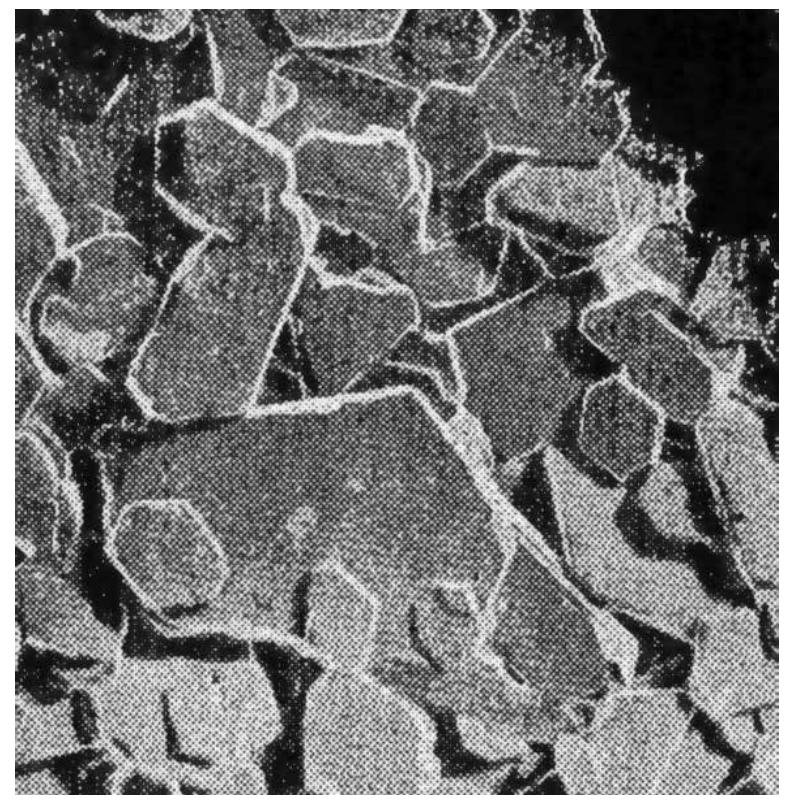

Рис. 1. Мікроструктура каоліну

Осадові глини зазвичай знаходяться в суміші зі значними кількостями слюди, кварцу і навіть частини польового шпату, що не розклався. Ці домішки повинні бути відокремлені. Осадові глини зазвичай мають більший розмір часток і меншу пластичність, ніж вторинні глини. Вторинні глини, як правило, мають дуже невеликий розмір часток, високу пластичність і менше забруднені грубозернистими мінеральними домішками. Однак присутність в них значної кількості органічних матеріалів більш ймовірно. Глини, що зазнали після утворення дії високих тисків, зазвичай ущільнені до такої міри, що вони є досить твердими, непластичними і такими, що важко диспергуються у воді. Для підвищення ефективності диспергування можливе застосування дискретно-імпульсного введення енергії за допомогою роторно-пульсаційних апаратів різних марок [2].

Крім основних глинистих мінералів, глини також містять різні кількості інших мінералів, що часто впливають на їхню поведінку при використанні. Найчастіше такими мінералами $є$ кварц, польові шпати і мінерали, що містять залізо, вапно, луги і розчинні солі. Органічна складова також міститься в багатьох глинистих відкладеннях. Різні класифікації глин грунтуються на їх геології, мінералогії, складі, властивостях і способах використання, але жодна з них не охоплює всієї можливої різноманітності [1].

\section{Результати та їх обговорення}

Каоліни можуть бути як первинними, так і вторинними. Вони є матеріалами що можуть мати як погану, так і досить хорошу пластичність. До типу пластичних відносяться осадові біловипалювальні глини із невеликим розміром частинок, що мають високі пластичність і міцність у висушеному стані.

Глини вогнетривкого типу не $є$ біловипалювальними, але вони вільні від таких плавнів, як залізо, лужноземельні і лужні метали, а також від надлишку кремнезему.

Сухарні глини включають в себе непластичні тверді вогнетривкі глини, що мають низьку вогневу усадку.

Гончарні глини. Під цим загальним терміном розуміють різноманітні жовтовипалювальні глини, що мають достатню пластичність, і вироби 3 яких можуть бути обпалені без втрати форми.

Глинисті сланці є твердими, непластичними, зазвичай скам'янілими глинами 3 низькою вогневої усадкою.

Спікливі глини ущільнюються під час випалювання при відносно невисоких температурах і зазвичай містять значну кількість заліза, а також мають відносно низьку вогневу усадку.

До групи цегляних відносяться лесові глини (глини, що утворилися в результаті діяльності вітру, що містять велику кількість кремнезему і лугів i мало глинозему), льодовикові глини (зазвичай піщанисті глини, що містять значні кількості заліза) і глини інших типів, вироби з яких можуть бути сформовані пластичним методом і обпалені при низькій температурі, даючи прийнятні забарвлення і текстуру. 
До групи поливів відносяться глини, що містять достатню кількість плавнів, повністю розплавляються при невисоких температурах. Вони використовуються для виготовлення емалей і в якості різних зв'язувань.

Тальк є водним силікатом магнію, який має шарувату структуру, подібну до структури глинистих мінералів. Його ідеальна формула $\mathrm{Mg}_{3}\left(\mathrm{Si}_{2} \mathrm{O}_{5}\right)_{2}(\mathrm{OH})_{2}$. Тальк є вторинним мінералом, що утворюється з силікатних гірських порід багатих магнієм. Найбільш небажаними з супутніх тальку мінералів, з керамічної точки зору, є сполуки заліза, що викликають при випалюванні зміну забарвлення і високі діелектричні втрати готових виробів. Присутність в ньому вапновмісних мінералів знижує точку розм'якшення матеріалу.

Тальк $є$ важливою керамічною сировиною для виробництва матеріалів, що використовуються в електротехніці та електроніці, а також для виготовлення плиток. Талькові маси легко формуються, а тальк в них служить джерелом магнезіальносілікатного розплаву при температурі випалу.

Пірофіліт $\mathrm{Mg}_{3}\left(\mathrm{Si}_{2} \mathrm{O}_{5}\right)_{2}(\mathrm{OH})_{2}$ має фізичні властивості, що практично ідентичні властивостям тальку, оскільки він має подібну ж структуру, в якій магній заміщений алюмінієм.

Масивний тальк легко обробляється, і після подрібнення має відчутну жирність. Часто його називають стеатітом. Після оброблення вироби з талькового каменю можуть бути обпалені при температурі близько $1000{ }^{\circ} \mathrm{C}$, при якій видаляється зв'язана вода і утворюється міцний черепок, що супроводжується невеликою усадкою.

Азбест. Таке найменування дано групі водних магнезіальносілікатних мінералів, що мають волокнисту структуру. Кристалічна структура цих мінералів характеризується наявністю довгих ланцюгів силікатних тетраедрів, що можуть легко розщеплюватися в напрямках, паралельних до силікатних ланцюгів, але не можуть розщеплюватися в напрямках, що їх перетинають, в результаті чого, ці мінерали можуть бути розділені на волокна. Вони утворилися за рахунок метаморфізму магнезіально-силікатних гірських порід. Головним представником цієї групи мінералів $\epsilon$ хризоліт $\mathrm{Mg}_{3}\left(\mathrm{Si}_{2} \mathrm{O}_{5}\right)_{2}(\mathrm{OH})_{4}$ - волокниста форма серпентину. Іншими промислово важливими різновидами азбесту є амозит і кросідоліт (блакитні азбести). Обидва представляють собою складні магнезіальні силікати, що класифікуються як амфіболи.

Розділені азбестові волокна використовуються в керамічній промисловості у вигляді крученого шнура або у вигляді тканини, або як заповнювач в теплоізоляційних і теплостійких конструкційних матеріалах [2].
Кремнезем $\mathrm{SiO}_{2}$ є головним інгредієнтом стекол, глазурей, емалей, вогнетривів, абразивів і тонкої кераміки. Двоокис кремнію широко використовується, так як він недорогий, твердий, хімічно стійкий і досить тугоплавкий, а також тому, що може утворювати скло. С велика різноманітність мінеральних форм, в яких зустрічається кремнезем. Але найбільш важливою, безсумнівно, є кварц, що використовується у вигляді великих, майже досконалих кристалів у формі кварцитової породи або кварцового піску. Кристалічна структура $\mathrm{SiO}_{2}$ така, що в ній $є$ мало простору для розміщення сторонніх атомів, в зв'язку з чим, кремній не може бути легко замінений іншими катіонами. Високоякісні кристали кварцу використовуються в оптиці і електроніці.

Головним джерелом кремнезему для керамічної промисловості є піски. Піски для виробництва скла повинні мати однорідний розмір зерен і високу чистоту. Особливо має бути низьким вміст заліза: менше $0,015 \%$ для оптичних стекол і менше 0,06 \% для листового і сортового скла. Цей же самий пісок зазвичай подрібнюють у кульових млинах до розміру часток менше 180 мкм для введення кремнеземутримуючого компонента в глазурі і тонкокерамічні маси.

Іншим важливим джерелом кремнезему є щільні кварцити, з яких виготовляють динасову цеглу для склепінь мартенівських, ванних, скловарних і коксових печей. Для цих цілей обираються породи, при подрібненні яких виходить суміш грубих і тонких зерен, а зміст $\mathrm{Fe}_{2} \mathrm{O}_{3}$ i $\mathrm{Al}_{2} \mathrm{O}_{3}$ не перевищує 0,5 \%. При цьому вміст вапна не лімітується, оскільки близько 0,5 \% $\mathrm{CaO}$ додається до шихти в процесі виробництва. Іншою формою кремнезему, що використовується в промисловості, є інфузорна земля, що представляє собою суміш зі скелетів найдрібніших морських тварин діатом (інфузорій). Майже на 90 \% вона складається із кремнезему і містить велику кількість мікроскопічних пір. В зв'язку з тим цей матеріал досить ефективно і широко використовується в якості теплової ізоляції [3].

Польові шпати є безводними алюмосилікатами, що містять катіони $\mathrm{K}^{+}, \mathrm{Na}^{+}$i $\mathrm{Ca}^{2+}$. Вони присутні практично у всіх вивержених породах. Ізоморфне заміщення в кристалічній гратці польового шпату одного катіона на інший призводить до утворення декількох різновидів. Найбільш важливими різновидами, що представляють промисловий інтерес, $\epsilon$ калієві польові шпати, які завжди містять деяку кількість альбіту, а натрієві - анортиту. Велику частину полевошпатової сировини дають пегматити, що представляють собою грубозернисті кристалічні породи, які утворилися на пізніх стадіях кристалізації магми. Утворення великих кристалів в таких породах прискорювалось за рахунок низької в'яз- 
кості та високої концентрації летючих складових. Головними супутніми мінералами в пегматитах $€$ кварц, слюда та інші силікати. Покращені методи збагачення пегматитів, що включають флотацію і магнітну сепарацію, роблять можливим отримання польового шпату, тоді як оброблення пегматитів старими методами економічно недоцільне.

Вільний кварц зменшує флюсову дію польового шпату. Його вплив більш ефективний в керамічних мaсах, що містять натрієвий шпат, ніж в тих, що містять калієвий шпат. Кількість і тип присутніх лугів визначають точку розм'якшення польового шпату, причому остання знижується при збільшенні вмісту натрію та зменшення вмісту калію.

Найголовнішим споживачем польового шпату є скляна промисловість, в якій він використовується як дешеве джерело окису алюмінію. Натрієвий шпат, в цьому випадку, кращий, оскільки він має більш низьку точку плавлення.

Польовий шпат для виробництва скла випускається 3 дисперсністю 20 мкм, в той час як інші галузі керамічної промисловості вважають за краще використовувати матеріал 3 дисперсністю до 200 мкм.

Нефеліновий сієніт є виверженою гірською породою, що не містить вільного кварцу і складається 3 нефеліну, альбіту і мікрокліну. Він може бути використаний як замінник польового шпату в скляній і порцеляновій промисловостях.

Воластоніт $\mathrm{CaSiO}_{3}$ набув широкого поширення як основна сировина для виготовлення фаянсу і плиток. Він все частіше використовується замість частини польового шпату, особливо в масах для виготовлення плиток.

Сіліманітова група мінералів, що мають склад $\mathrm{Al}_{2} \mathrm{SiO}_{5}$, грає важливу роль в виробництві мулітових вогнетривів. Мінерали цієї групи зустрічаються в трьох поліморфних формах - силіманіт, кіаніт і андалузит. Всі вони мають властивість при нагріванні до відповідних температур утворювати муліт та кремнезем. Залежно від теплового оброблення i присутності плавнів, кремнезем в таких матеріалах 3'являється у вигляді скла. Найбільше використання знаходить кіаніт. При випалюванні він дає значне розширення, в зв'язку з чим, при виготовленні мулітової цегли, він зазвичай піддається попередній термообробці. Спечений синтетичний муліт, що отриманий на основі малозалізистих бокситів, анітрохи не поступається за властивостями муліту, отриманому із природних мінералів.

Окис алюмінію. Мінерали гідрату алюмінію утворені, головним чином, при розкладанні алюмосилікатних порід, що раніше існували в родовищах та містили воду. Відносна розчинність окису алюмінію і кремнезему в грунтових водах залежить від значення $\mathrm{pH}$ середовища, як це вже зазначалося вище, при розгляді генезису глин. Окис алюмінію легкорозчинний при $\mathrm{pH}$, що дорівнює 4, а кремнезем розчиняється. Однак в інтервалі значень $\mathrm{pH}$ від 5 до 9 окис алюмінію практично нерозчинний, а розчинність кремнезему збільшується.

Окис алюмінію. Найбільша кількість бокситів в керамічної промисловості використовують для виробництва абразивів. Крім того, вони використовуються для виробництва високоглиноземистих вогнетривів і глиноземистих цементів. Окис алюмінію, що використовується для виготовлення абразивів, утворюється з бокситу за байеровським процесом. Цей процес полягає у вибірковому вилуговуванні окису алюмінію в автоклаві розчином каустичної соди. В результаті цього відбувається осадження $\mathrm{Al}(\mathrm{OH})_{3}$, чистота якої досягає 99,5 - 99,8 \%.

Окис магнію. Окис магнію утворюється головним чином 3 природного магнезиту $\mathrm{MgCO}_{3}$ і з гідроксиду магнію $\mathrm{Mg}(\mathrm{OH})_{2}$, що отримується 3 морської води або сольових розчинів. Близько половини продукції окису магнію, що випускається в США для виготовлення вогнетривів, отримують 3 вищезгаданого джерела. Невелика кількість окису магнію отримують 3 природного бруситу.

У природі зустрічаються кристалічний і псевдокристалічний типи магнезиту. Перший утворюється 3 магнезіальносілікатних порід, а другий в результаті заміщення кальцію в доломіті та вапняку. Псевдокристалічні відкладення зазвичай дуже малі та менш поширені, ніж родовища кристалічних різновидів, але зазвичай вони містять більш чистий матеріал.

Окис магнію 3 морської води отримують при взаємодії останньої з прожареним доломітом. При цьому, в готовий продукт близько половини окису магнію переходить 3 морської води і половина 3 прожареного доломіту. Всі магнійвмісні матеріали перед використанням піддають прожарюванню: каустичний окис магнію отримують 3 магнезиту шляхом прожарювання при температурах нижче $1560{ }^{\circ} \mathrm{C}$ до залишкового вмісту $\mathrm{CO}_{2}$, що дорівнює 2 - $10 \%$. Намертво обпалений окис магнію отримують шляхом прожарювання природної сировини або окису магнію, що отриманий 3 морської води при температурах від 1560 до $1760{ }^{\circ} \mathrm{C}$ до утворення щільного стабільного продукту.

Доломіт. Гірська порода, що складається, в основному, з мінералу доломіту, що представляє собою твердий розчин карбонатів кальцію і магнію 3 формулою $\mathrm{CaMg}\left(\mathrm{CO}_{3}\right)_{2}$, $є$ найбільш широко поширеним основним сировинним матеріалом із високою точкою плавлення. У вигляді кальцинованих агрегатів доломіт широко використовують у металургійній промисловості для гарячого ремонту подин мартенівських печей. Цеглини, що виготов- 
лені з прожареного доломіту, руйнуються через гідратацію вільного вапна, а також із-за поліморфного перетворення, що відбувається при охолодженні в двохкальціевому силікаті, який утворився в матеріалі при високих температурах. Стабілізовану доломітову цеглу виготовляють, переводячи вільне вапно в силікати або ферити, зазвичай шляхом введення додавань серпентину або окису заліза, або шляхом введення додавань бору, фосфатів або інших стабілізаторів, що запобігають поліморфному перетворенню двохкальцієвого силікату. Частково стабілізовану цеглу виготовляють, покриваючи кальцинований доломіт смоляними або скловидними зв'язуваннями, що запобігають його гідратації. Тонка фракція доломітової шихти може бути замінена окисом магнію, що також може сприяти уповільненню взаємодії вільного вапна із вологою. Стабілізована доломітова цегла є найважливішим вогнетривом, використовуваним на сталеплавильних заводах [4]. Доломітова цегла на смоляному зв'язуванні широко використовується в подинах конверторів 3 кисневим дуттям, що призначені для виробництва сталі.

Хромова руда. Головною складовою частиною хромових руд є складні тверді розчини шпинелей $(\mathrm{Mg}, \mathrm{Fe})(\mathrm{Al}, \mathrm{Cr})_{2} \mathrm{O}_{4}$, вміст яких в матеріалі коливається від 70 до $90 \%$. Інша частина складається 3 різних магнезіальних силікатів та інших мінералів: кальциту, доломіту, магнезиту і т.д. Хромові руди утворюються при кристалізації основних магм. Причому тип мінералів, що утворюються, дуже сильно залежить від самих незначних змін у складі навколишньої магми. Склад і структура хромових руд вельми різноманітні. Ті з них, що використовують для виготовлення вогнетривів, мають, взагалі, низький вміст хрому, в той час, як високосортні руди використовуються як джерело металевого хрому.

Зміст $\mathrm{FeO}$ в основному компоненті руди має важливий вплив на іiї придатність для виготовлення вогнетривів. Руди з високим вмістом $\mathrm{FeO}$ виявляють значне розширення при випалюванні, а також при контакті 3 оксидами заліза при підвищених температурах. Кількість і характер магнезіальних силікатів також спричиняють значний вплив на властивості руди. Про кількість силікатів, що присутні в руді, можна судити за змістом $\mathrm{SiO}_{2}$. У більшості руд, придатних для використання, вміст $\mathrm{SiO}_{2}$ лежить в межах від 3 до $6 \%$; при вмісті $\mathrm{SiO}_{2}$ менше $3 \%$ руда зазвичай занадто крихка, в той час як цеглини, виготовлені з руд 3 вмістом $\mathrm{SiO}_{2}$ більше $6 \%$, мають знижену шлакостійкість. Вапно утворює легкоплавкі з'єднання, і його присутність в кількостях, що перевищують 10 \%, небажана. Кам'янисті руди $\epsilon$ кращими для виготовлення вогнетривів, оскільки вони забезпечують необхідний високий вміст грубих фракцій. Пухкі руди використовують, головним чином, у відповідних композиціях для виготовлення обмазок, що застосовуються для гарячого ремонту печей [4].

При виготовленні вогнетривів, що призначені для футерування мартенівських печей, хромова руда використовується головним чином в сумішах із намертво обпаленим окисом магнію.

Найважливішим джерелом лугів, що необхідні для скляної промисловості, $\epsilon$ кальцинована сода $\left(\mathrm{Na}_{2} \mathrm{CO}_{3}\right)$, що виготовляється, головним чином, 3 хлористого натрію, а не видобувається в вигляді природного матеріалу. Концентровані розчини хлористого натрію зазвичай карбонізують сумішшю аміаку і вуглекислого газу, в результаті чого осідає бікарбонат натрію, який піддають зневодненню шляхом прожарювання. Велика кількість інших солей натрію також придатна для використання, але в керамічної промисловості вони застосовуються лише в невеликих кількостях.

Водні натрій-боратні мінерали є головним джерелом натрію та бору, що використовуються в якості плавнів. Керн $\mathrm{Na}_{2} \mathrm{~B}_{4} \mathrm{O}_{7} \cdot 4 \mathrm{H}_{2} \mathrm{O}$ і бура $\mathrm{Na}_{2} \mathrm{~B}_{4} \mathrm{O}_{7} \cdot 10 \mathrm{H}_{2} \mathrm{O}$ дають переважну частину боровмісних природних сполук. Інша частина видобувається, головним чином, $з$ різних розсолів.

Плавиковий шиат. Фтор є сильним плавнем в силікатних системах. Найбільш важливим його джерелом є мінерал флюорит (плавиковий шпат) $\mathrm{CaF}_{2}$, поклади якого зазвичай зустрічаються у вигляді жил як в осадових, так і у вивержених породах. Керамічні сорти плавикового шпату досить чисті та часто містять до $95 \% \mathrm{CaF}_{2}, 2,5 \% \mathrm{SiO}_{2}$ i 1,5\% $\mathrm{CaCO}_{3}$.

Фосфатні мінерали або хімічні реактиви, що одержуються з них, використовують в значних кількостях в якості плавнів. Апатити $\mathrm{Ca}_{5}(\mathrm{OH}, \mathrm{F})\left(\mathrm{PO}_{4}\right)_{3}$ $\epsilon$ головною промислово важливою групою фосфатних мінералів, що є основною складовою фосфатних гірських порід, знайдених у багатьох родовищах.

Для виробництва абразивних виробів використовують, головним чином, спеціально виготовлені сировинні матеріали, такі як карбід кремнію і плавлений окис алюмінію. Для спеціальних цілей використовуються також природні абразивні мінерали, такі як кварцовий пісок, гранат і наждак.

Карбід кремнію отримують шляхом електричного нагрівання сумішей піску і вугілля до температури близькій $2200{ }^{\circ} \mathrm{C}$, при якій вони реагують 3 утворенням SiC i CO. Продукуються два типи карборунду: відносно забруднений чорний карборунд, що містить близько 98 \% $\mathrm{SiC}$, і зелений карборунд, що отримується 3 найчистіших сировинних матеріалів, що містить до 99,7 \% SiC. Карбід кремнію подрібнюють і класифікують за розміром частинок, і в такому вигляді використовують для виробництва абразивних інструментів та інших виробів. 
Окис алюмінію, що використовується для виготовлення абразивів, виготовляється шляхом плавлення бокситу або технічного окису алюмінію в дугових печах з графітовими електродами. 3 прожареного бокситу отримують щільний і напівпухкий сорти окису алюмінію, в яких містяться від 95 до $97 \% \mathrm{Al}_{2} \mathrm{O}_{3}$ і значні кількості $\mathrm{TiO}_{2} \mathrm{i} \mathrm{SiO}_{2}$. Щільність такого продукту є наслідком наявності домішок двоокису титану. Для відновлення окису заліза і кремнезему в процесі виробництва в шихту додають вуглець. Одночасне додаткове введення домішок металевого заліза забезпечує утворення феросиліцію, що володіє магнітними властивостями і високою питомою вагою, тобто якостями, що полегшують його відділенню. Пухкий окис алюмінію, що містить більше $99 \% \mathrm{Al}_{2} \mathrm{O}_{3}$, виходить подібним чином $з$ байеровського глинозему.

При виготовленні конденсаторів 3 титанату барію потрібно використовувати в якості сировинних матеріалів хімічно чисті двоокис титану і карбонат барію. Подібним же чином магнітна кераміка виробляється 3 хімічно осадженого окису заліза. Ядерні паливні елементи виготовляють 3 двоокису урану, що отриманий хімічним шляхом. Берилісву кераміку виготовляють 3 осадженого і прожареного окису берилію. Високоглиноземну кераміку для свічок запалювання та електроніки виробляють головним чином 3 прожареного окису алюмінію, що отриманий за байеровським процесом. Приготовлені хімічним шляхом флюси, такі як карбонати барію і стронцію, також знаходять широке застосування.

\section{Висновки}

Виробництво більшості традиційних керамічних матеріалів засноване на використанні недорогої, відносно доступної сировини, хімічне оброблення якої недоцільне з міркувань його вартості.

У найбільших розмірах хімічне оброблення сировинних матеріалів для керамічної промисловості, безсумнівно, знаходить застосування у виробництві окису магнію з морської води, технічного глинозему і кальцинованої соди.

Однак для виробництва все більшої кількості спеціальних виробів використовують сировинні матеріали, що отримані хімічними методами, причому їх практичне значення збільшується зі зростанням ціни одиниці продукції, що виготовляється. У виробництві окремих типів функціональної спеціальної кераміки висока вартість готових виробів і жорсткі вимоги до відповідних властивостей і допускам обумовлюють необхідність високого рівня контролю всіх вихідних матеріалів.

\section{References}

1. У.Д. Кингери. Введение в керамику. Пер. с англ. А.И. Рабухина и В.К. Яновского, под ред. П.П. Будникова и Д.Н. Полубояринова. - М.: Издательство литературы по строительству. - 1987. - 499 с.

2. Корчинський, О.А., Опєкунов, В.В., Матюшкін, $M . B$. Розпушення азбестових волокон за методом дискретно-імпульсного введення енергії. Кераміка: наука і життя. - № 3(1). - 2009. - С. 7 - 16.

3. Крючков, Ю.Н. Структурные параметры пористых монодисперсных керамических материалов. Огнеупоры и техническая керамика. - №9. - 1999. - C. 25 - 32.

4. Лебедев, М.Б., Казакова, Л.Н. Возможности энергосбережения при эксплуатации обжиговых печей, футерованных шамотно-волокнистыми материалами. Огнеупоры и техническая керамика. - №2. 2008. - C. 15 - 23. 